\title{
Stílusváltozatok a világ rendészeti járványkezelésében
}

\author{
Cieleszky Péter ${ }^{1}$, Finszter Géza ${ }^{2}$ \\ ${ }^{1}$ Nemzeti Közszolgálati Egyetem Rendészettudományi Doktori Iskola, Budapest, Magyarország \\ ${ }^{2}$ Nemzeti Közszolgálati Egyetem Rendészettudományi Kar, Budapest, Magyarország \\ Beérkezett: 2021. augusztus 26.; Elfogadva: 2021. szeptember 28.
}

\begin{abstract}
Összefoglalás
A világjárvány a Föld minden országát fenyegeti. Az ellene folytatott küzdelem eredményeit és kudarcait akkor lehet felmérni, ha a veszély elmúlt. Addig csak a vírus támadásának a más társadalmi kockázatoktól eltérő egyedi tulajdonságai tárhatóak fel. Tanulmányozásra várnak az egyes országokban bevezetett rendkívüli intézkedések és az Egészségügyi Világszervezet (WHO) globális védekezésre tett kezdeményezései.
\end{abstract}

Kulcsszavak: világjárvány, rendkívüli jogrend, globális védekezés, Egészségügyi Világszervezet (WHO)

\author{
Varieties of Style in Law Enforcement Dealing with the Pandemic \\ Péter Cieleszky ${ }^{1}$, Géza Finszter ${ }^{2}$ \\ ${ }^{1}$ National University of Public Service, Doctoral School of Law Enforcement, PhD student, Budapest, Hungary \\ ${ }^{2}$ National University of Public Service, Faculty of Law Enforcement, Budapest, Hungary
}

\section{Summary}

The time has not yet come for a comprehensive assessment of the COVID-19 pandemic situation. At this stage, it is possible to collect information, formulate incomplete hypotheses, and define possible research directions and methodology. With this in mind, our paper will focus primarily on domestic practices. We will study the legislation, the constitutional basis of the special legal order, the functioning of public administration organisation, the reactions of criminal substantive and procedural law and, finally, the changed tasks and functions of law enforcement administration in the emergency situation.

On the basis of the information available to us, we are seeking answers to three questions.

Firstly, can the pandemic be considered a global threat to societies, one with specific characteristics that are different from all other threats?

Secondly, what role do the state, government in general, and public administration authorities and law enforcement in particular, have to play in combating the pandemic?

Thirdly, can international cooperation achieve such a level of global capacity for action that is needed to tackle the global threat?

In response to the first question, the study describes the specificities that justify the uniqueness of the pandemic in nine points:

- the classification as the highest risk,

- the three hazards theory,

- the incomparable nature of the consequences of pandemics and natural disasters,

- the exclusion of any prior consideration of risk-taking,

- the application of the tolerable and intolerable distinction,

- the inconsistency of the typology of internal and external risks,

- a characteristic that cannot be predicted by legislation,

- the mathematical measurability of consequences, and

- the impact on the world economy.

Our second aim was to present the domestic practice of combating the epidemic through the special legal order, drawing on the evaluations of legal scholars on the subject published since 2020. We have reviewed the constitution- 
ality of the special legal order, its impact on central state and municipal administration, on substantive and procedural criminal law, and on law enforcement administration. Attention was paid to a specific institution dictated by the exceptional situation: the hospital command system. The police officers temporarily appointed to this post are responsible for supporting the organisational work in health institutions, which cannot include medical activities requiring medical training.

The third theme focused on the World Health Organisation's response to the epidemic from a global perspective. We recalled that the idea of an international treaty was first raised by the President of the European Council, Charles Michel, at the Paris Peace Forum in November 2020 and subsequently endorsed by the G7 leaders on 19 February 2021. EU leaders then expressed their commitment to start work on the preparation of an international treaty on pandemics in the framework of the World Health Organisation.

We are convinced that this threefold approach will be worth pursuing when the opportunity arises to assess good and bad practices in epidemic management. However, this will be a task for the post-COVID era.

Keywords: Pandemic, extraordinary state of law, global protection, World Health Organization (WHO)

\section{Bevezetés}

A SARS-CoV-2-vírus által okozott megbetegedések tömeges elterjedésével 2020-ra pandémiás járványhelyzet alakult ki a Földön. A kihívás rövid időn belül vált globálissá. A Kínai Népköztársaság 2019. december 31-én Wuhan városából 44 ismeretlen eredetú tüdőgyulladásos esetet jelentett az Egészségügyi Világszervezet (a továbbiakban: WHO) felé. Az elkövetkező hónapban Kínán belül a megerősített új esetek száma 7736-ra emelkedett, 170 halálesetet regisztráltak. Kínán kívül 18 országból mintegy 82 esetben erősítették meg a betegséget ${ }^{1}$. A világszervezet 2020. január 30-án a legmagasabb szintú riasztás kiadása feltételeinek megléte okán - fennállása alatt hatodik alkalommal ${ }^{2}$ - nemzetközi horderejü járványügyi szükséghelyzetet (PHEIC - public health emergency of international concern) hirdetett ${ }^{3}$.

2020 februárjának második hetében a betegség hivatalos nevet kapott (coronavirus disease 2019), amelynek rövidítése az ismert COVID-19 betûszó lett. Február 19-étôl a WHO heti tájékoztatókat ad ki a járványhelyzetről és a járvány terjedéséról. Ez utóbbi dinamikáját jelzi, hogy egy hónappal a szükséghelyzet kihirdetését követően Kínán belül a megerősített esetek száma közel 80 ezerre nőtt, Kínán kívül pedig 53 országot érintve a 6 ezret meghaladta. ${ }^{4} 2020$. március 13 -án a WHO fóigazgatója megállapította, hogy Európa vált a világjárvány centrumává, tekintve, hogy több esetet és halálesetet jelentettek, mint a Kínai Népköztársaságot leszámítva a világ többi részéról ${ }^{5}$. Ez volt a kezdet... Majd eltelt szúk másfél év. A harmadik hullám lecsen-

\footnotetext{
https://www.who.int/docs/default-source/coronaviruse/situation reports /20200130-sitrep-10-ncov.pdf?sfvrsn=d0b2e480_2.

2009 sertésinfluenza, 2014 járványos gyermekbénulás, 2014 Ebola járvány, 2016 Zika-vírus, 2019 Ebola járvány, 2020 COVID-19.

${ }^{3}$ https://www.who.int/emergencies/diseases/novel-coronavirus-2019/interactive-timeline\#!

${ }^{4}$ https://www.who.int/docs/default-source/coronaviruse/situationreports $/ 20200229$-sitrep-40-covid-19.pdf?sfvrsn=849d0665_2.

5 https://www.who.int/director-general/speeches/detail/who-director-general-s-opening-remarks-at-the-mission-briefing-on-covid-19---13-march-2020.
}

góben van. Várakozunk, a szakértók a negyedik hullámról beszélnek ${ }^{6}$.

A cikk készítésekor ${ }^{7}$ - a WHO 2021. július 6-án közzétett adatai szerint - a SARS-CoV-2-vírus által okozott igazolt megbetegedések száma globálisan meghaladta a 183 milliót, közel 4 millió ember halálát okozva. Azóta az áldozatok száma meghaladta a 4 milliót. A vírus mutálódása során annak változatai közül az Alpha 173, a Béta 122, a Gamma 74 és a Delta 104 országban jelent $\mathrm{meg}^{8}$. A lakosság átoltottsága emelkedik, de ennek ténye aligha akadályozza meg a járvány negyedik hullámának megérkezését.

Emellett a vírus mutációi újabb kihívások elé állítják a társadalmakat, a betegségen átesettek körében jelentős számban - a hosszabb távú egészségkárosító hatások elkerülése okán - utókezelés szükségessége merült fel. Magyarországon éppen ennek okán készültt el 2021 márciusában a Post COVID-19 szindróma szakmai protokollja9.

A SARS-CoV-2 eredetét vizsgáló, a világszervezet közgyúlésének WHA73.1 számú Határozatában felhatalmazott nemzetközi kutatócsoport 2021 márciusában tette közzé jelentését. A vírus eredetével összefüggésben nem zárták ki a laboratóriumi szivárgás esetét sem, bár azt a legkevésbé valószínúként jelölték. A WHO főigazgatója hangsúlyozta, hogy továbbra is szilárdan elkötelezett a vírus etiológiája kutatásában. ${ }^{10}$

\section{Az elôzmények}

A járványokra és a járványhelyzetekre való felkészülésnek voltak korábbról hasznosítható tapasztalatai. A történelmi világjárványok közül napjainkra az influenzavírus

\footnotetext{
${ }^{6}$ https://hvg.hu/itthon/20210710_Jakab_Ferenc_a_jarvany_4_hullamarol_ Kis_szerencsevel_az_augusztust_meg_megusszuk.

${ }^{7}$ A kézirat lezárásának időpontja 2021. július 18.

${ }^{8}$ https://www.who.int/publications/m/item/weekly-epidemiological-upda te-on-covid-19---6-july-2021.

${ }^{9}$ https://mok.hu/koronavirus/tajekoztatok/post-covid-szindroma-diagnosz tika-es-protokoll.

${ }^{10}$ https://www.who.int/director-general/speeches/detail/who-director-general-s-remarks-at-the-member-state-briefing-on-the-report-of-the-international-team-studying-the-origins-of-sars-cov- 2 .
} 
(annak is A variánsa) által okozott megbetegedések pandemikus potenciálja a legerósebb. Ismert a világszerte 4 hónap leforgása alatt több tízmillió áldozatot követelő, az Egyesült Államokból elterjedő 1918-as spanyolnátha járvány, amely az emberiség egyharmadát fertőzte meg, és áldozatainak számát 20-40 millióra becsülik. Világjárványként rögzítették az 1889-es, az 1957-es ázsiai (H2N2), az 1968-as hongkongi (H3N2) és az 1977-es orosz influenzajárványokat is - az utóbbi a nevével ellentétben ugyancsak Kínából indult ki. Bár pontos adatok nincsenek, de becslések szerint az ázsiai influenza 1 millió ember életét követelte, az 1968-as tömeges fertőzés pedig Hongkong lakosságának 15\%-át érte el, és világszerte 1-3 millió ember halálát okozta ${ }^{11}$. A 2009-es H1N1 influenzavírus - amelynek nyomán a WHO az elmúlt bő három évtized első influenzajárványát kihirdette - megjelenésének első évében világszerte több százezer áldozatot szedett. ${ }^{12}$

Az influenzavírus által okozott megbetegedések nyomán kialakuló járványok elmúlt másfél évszázados tapasztalatai mellett az emberiség előtt ismertek voltak egyéb világjárványok - például a középkori pestisjárványok, a 19. századi kolerajárvány, későbbről pedig például az AIDS - tapasztalatai is. Ezen túlmenően pedig jelentős volt azon fertőző betegségek száma is, amelyek nem pandémiás típusú, hanem sporadikus (Lyme-kór), endémiás (malária) és epidémiás (Ebola) előfordulással jelentek és jelennek meg.

A témakör hozzáértő szakemberei között vannak, akik vallják, a COVID-19 pandémia nem előzmények nélküli esemény, ezért amennyiben készületlenül érte az emberiséget, az arra mutat, hogy világunk rosszul múködik. Mások viszont nem ennyire szigorúak, és azt hangoztatják, hogy ilyen méretű járvány nem volt prognosztizálható, a veszélynek azzal a minőségével van dolgunk, amelyre az emberi történelemben eddig nem volt példa.

\section{A kutatás tárgya és módszertana}

A COVID-19 pandémiás helyzet átfogó értékelésének ideje még nem érkezett el. Jelenleg az információk gyưjtésére, a hipotézisek nem teljes körü megfogalmazására, a lehetséges kutatási irányok és a módszertan meghatározására nyílik lehetőség. Figyelemmel erre, dolgozatunk elsődlegesen a hazai gyakorlatot veszi górcső alá. Tanulmányozzuk a jogalkotást, a különleges jogrend alkotmányos alapjait, a közigazgatási szervezet múködését, a büntető anyagi és eljárásjogi reakciókat, végül a rendészeti igazgatásnak a veszélyhelyzetben megváltozott feladatait és funkcióit.

A számunkra elérhető információk alapján három kérdésre keressük a választ.

\footnotetext{
${ }^{11}$ https://www.who.int/news-room/feature-stories/detail/preventing-thenext-human-influenza-pandemic-celebrating-10-years-of-the-pandemic-influenza-preparedness-framework.

12 https://www.cdc.gov/flu/pandemic-resources/2009-hlnl-pandemic.html.
}

Először: a világjárvány tekinthető-e a társadalmakat fenyegető olyan globális veszélynek, ami minden más fenyegetéstől különböző, egyedi vonásokkal rendelkezik?

Másodszor: a világjárvány legyőzésében milyen szerep vár az államra, általában a kormányra és a közigazgatási hatóságokra, különösen pedig a rendészeti igazgatásra?

Harmadszor: nemzetközi összefogással elérhető-e a globális cselekvőképességnek az a szintje, ami a globális veszély elhárításához szükséges?

\section{A világjárvány egyedisége}

A világjárvány minden más veszélytől megkülönböztethető vonásait a következőkben találtuk:

- Az emberi társadalmat sújtó legnagyobb kockázat, mert példátlan módon, egy meghatározott időpontban a Föld valamennyi lakosának életét egyszerre fenyegeti. (Ilyen helyzetet csak egy kozmikus katasztrófa lenne képes elóállítani, aminek azonban igen kicsi a valószínúsége, míg a járvány realitás.)

- Oksági hátterében megtalálható mindhárom veszélyforrás, a természet, a természet és az emberi közösségek valamennyi interakciója, és végül a társadalmak belső múködésének teljessége. „Az emberiség eljutott abba a fejlettségi állapotba, amikor csak kevés olyan gazdasági tevékenység ismert, amelyik mentes a különféle (például szociális, egészségügyi, gazdasági, környezeti) jelen és jövőidejû rizikófaktoroktól." (Irk 2015: 87)

- A veszélyforrások összetettsége nem jelenti azt, hogy a világjárvány és a természeti katasztrófák következményeikben összevethetők lennének. Ezt támasztja alá az amerikai szakirodalom a következő érveléssel, amit Nagy Ivett, a Rendészettudományi Doktori Iskola hallgatója, egyelőre csupán kéziratban elérhető recenziójában idéz a hivatkozott tanulmányból: „Példaként hozza a különbséget egy természeti katasztrófa és egy világjárvány között, mely szerint a természeti katasztrófa adott földrajzi területen pusztít és rövid idő alatt megy végbe, a világjárványban viszont egyszerre több államot (országot) érint, hosszabb ideig tart és globális szintû kihívásokat jelent. A történelem során már volt példa arra, hogy a bünüldöző szerveknek, a kormánynak és az egészségügyben dolgozóknak is meg kellett küzdeni egy-egy járvánnyal (például H1Nl influenza 1918-ban és 2009-ben)." (Jennings-Perez 2020)

- Más veszélyekkel szemben itt nincs lehetóség elózetes mérlegelésre, nem beszélhetünk vállalható vagy nem vállalható kockázatokról, a minősítéshez csak az elviselhetetlen vagy az elviselhető mérték jöhet szóba. „A 2019-ben kirobbant COVID-19 járvány kockázatelemzésében egy 2014-ben Kínában, a korábbi SARSjárvány tapasztalatai alapján született matematikai modellt használunk, mert a járványterjedés mechanizmusa azonos (vagyis nyálkahártyán keresztül cseppfertőzéssel terjed)... A kínai kutatók a járvány 11 kocká- 
zati tényezőre vezették vissza, és kimutatták ezek logikai kapcsolatát a járvány elfogadhatatlan, illetve elfogadható (elviselhető) következményeivel." (Bukovics-Kun-Szendró, 2021: 137)

- Az emberi tevékenységek fö szabályként úgy teremthetik meg belső biztonságukat, hogy közben a tevékenységekben részt nem vevők külső biztonságáról is képesek gondoskodni (Irk 2015: 89). Ez a harmónia vész el a világjárvány elleni védekezés során, minthogy a járványveszély elhárítása úgyszólván valamennyi társadalmi aktivitás időleges leállításától vagy azok jelentős szúkítésétől remélhetô. A belsô és a külső kockázat közötti különbség tételt a világjárvány lehetetlenné teszi, abban mindenki belsöként érintett. A rendkívüli helyzetre elő́rt rendszabályok - a karanténtól a maszkviselésen át egészen a kijárási tilalomig - mindenkire érvényesek.

- A világjárvány totális kockázat, ami éppen egyediségére tekintettel nem prognosztizálható az anyagi jogalkotás módszerével, annak ellenére sem, hogy a „kockázat olyan veszélyekhez kapcsolódik, amelyeket a jövő öszszefüggésében értékelünk" (Irk 2015: 89). A jogalkotás csakugyan a jövőnek szól, de tárgya nem az egyszeri és egyedi esemény, hanem az általános és a tipikus, márpedig éppen ezeket a tulajdonságokat nem leljük a pandémiában. „A közigazgatási jogban a veszélyek - kissé önkényesen - két csoportra oszthatók, az egyik csoportba azok a fenyegető tények tartoznak, amelyek előre nem láthatóak, az ellenük való védekezési lehetőségek ezért igencsak behatároltak. Ezekre az általános, vagy ismeretlen veszélyekre vonatkozó jogi szabályozást jórészt a közigazgatási eljárásjogban találjuk meg." (Fábián 2021: 197) Továbbá az alkotmányjogban a különleges jogrend intézményében!

- A totális kockázat nem prognosztizálható, de bekövetkezését követően olyan markáns és statisztikailag mérhető következmény-tömeget hagy maga után, ami jövőbeni alakulását megbecsülhetővé teszi. „A sikeres modellezéshez azonban pontos és friss adatokra van szükség, amelyek nemcsak az emberek pillanatnyi szokásairól, hanem kapcsolati és mobilitási mintázataikról, valamint azok változásáról is pontos képet adnak. Egy ilyen adatgyújtést elősegítő rendszert és az abból kinyert eredményeket mutatja be dr. Karsai Márton, a Közép-európai Egyetem Hálózat- és Adattudományi Tanszékének egyetemi docense, aki a koronavírusjárvány által okozott kapcsolattartási és társadalmi változásokat kutató, a Szegedi Tudományegyetem munkatársai által múködtetett Magyar Adatszolgáltató Kérdőív (MASZK) adatelemző csoportjának vezetője.”13 A totális kockázat is „mérhető bizonytalanság” (Irk 2015: 88), ezért a világjárvány leküzdése

\footnotetext{
${ }^{13}$ https://mta.hu/tudomanyunnep2020/karsai-marton-fertozesterjedesek adatalapu-modellezese-avagy-halozatok-a-koronavirus-jarvany-modellezesenek-szolgalataban-111049.
}

megtervezhető, megszervezhető és az ezt szolgáló döntések hatékonysága ellenőrizhető!

- A jelenlegi egészségügyi krízis gazdasági világválsággal fenyeget. Ez abban különbözik a világgazdaság múltban előforduló nagy összeomlásaitól, hogy azok oka sok esetben a túltermelés volt, jelenleg viszont a termelő kapacitások és a piacok múködésének leállása, de legalább alapos visszaesése szüli a hiányokat, és ez a hiány lehet a globális gazdasági válság fó oka. A kérdéskör közgazdasági elemzést igényel, ami meghaladja e dolgozat szerzőinek kompetenciáját.

A világjárvány nem az általa keltett veszélyek nagyságával, hanem egyediségével jelent páratlan kihívást az emberiség számára. A veszélyek nem nagyobbak, mint a járványok történetében bármikor korábban. A korszakok között nem a kockázatok nagyságában van a különbség, hanem a társadalmi cselekvést megalapozó ismeretekben, a veszélyeknek való kiszolgáltatottság mértékében, a lehetséges védekezési módszerek hiányában vagy gazdagságában, és végül a fenyegetések térbeli és időbeli terjedésében (Finszter 2019: 942). Ez a számvetés részben derúre adhat okot, mert napjainkban mind a társadalmi cselekvést megalapozó ismeretek, mind pedig a védekezési módszerek tekintetében elődeinknél jóval kedvezőbb helyzetben vagyunk, ami csökkenti a kiszolgáltatottságot. Ugyanakkor a globalizáció mértéke a fenyegetések hatókörét térben és időben úgy kiterjesztette, hogy a fertózéssel érintett terület nagysága és a járvány terjedési sebessége messze meghaladja a korábban észlelt értékeket. Ez aggodalomra ad okot. A világ először került szembe az emberiség egészét fenyegető veszéllyel, amelyre csakugyan globális választ kellene adni, olyan időben, amikor a globalizációs folyamat állapota, és különösen annak belső ellentmondásai ezt nem teszik lehetôvé (Szücs 2020: 1124).

A kialakult helyzetet a veszélyek komplexitása súlyosbítja: „...olyan veszélyekkel kell szembenéznünk, amelyek a történelem során soha nem fenyegették az emberiséget. A gazdasági összeomlást, a piacokat szabályozó láthatatlan kéz csődjét megtapasztalhattuk 2008-ban, a terrorizmus fenyegetése 2001 9/11 óta nem hasonlítható semmi korábbihoz, a klímakatasztrófa pedig elkerülhetetlen, ha a világ berendezkedése nem változik." (Finszter 2019: 936-937) A komplexitás nem lenne teljes a migráció említése nélkül, ami ugyan közvetlen kapcsolatokat nem mutat a világjárvánnyal, de a jövőben újabb kockázati tényezőt jelenthet: „E szerint a humán migráció és a pandémia közötti kapcsolat lehetőségét el kell ismerni, az rejt magában kockázatot, veszélyt." (Éberbardt 2021b: 345)

A modernitás a társadalmi cselekvéseket megalapozó ismeretek gyarapodását hozta el, ami a képességek globalizációjával járt. Ennek a lendületnek az eredménye az emberi tevékenységek globalizációja, az ára pedig a veszélyek globális méretû́ kiterjedése. A szellemi és anyagi értékek igazságos elosztásának és a veszélyvállalásnak a felelőssége egyetemes erkölcsi értékrend kialakítását sür- 
geti. „Az emberi történelemben először az emberi lényeknek planetáris felelősséget kell vállalni.” (Heller 2001: 45) Csakhogy egy ilyen vállalásnak akadálya lehet, hogy a különböző veszélyek egymásnak ellentmondó értékrendet szülnek. Példának okáért a világjárvány leküzdése a nemzetállamok között szolidaritást és toleranciát követel, ugyanakkor a migrációtól való félelem a bezárkózást és az intoleranciát növeli. Az a politikai berendezkedés számíthat sikerre, amelyik képes szembenézni ezekkel az ellentmondásokkal, és a megoldások kutatásában számít a társadalomtudományokra.

$\mathrm{Az}$ új veszélyek megváltozott kezelési technikákat követelnek. A veszélyelhárítás jog által szabályozható módozatait célszerú elkülöníteni a jog által nem szabályozható, illetve a nem jogi, hanem más típusú normákkal és tudással (szakmai kompetenciák) kezelhetô területektől (Irk 2004). A legsúlyosabb próbatételen az egészségügyi rendszernek kell átmennie, minthogy egyetlen ország sem képes „békeidőben” olyan hálózatot üzemeltetni, amelyik alkalmas lenne a váratlanul támadó világjárványban megbetegedett tömegek fogadására. Ezt a rendkívüli helyzetet csak az orvosi kompetenciától különböző, az állam által vezérelt szervezeti és hatósági döntések sorozatával lehetséges megoldani, úgy azonban, hogy ezek segítsék, és ne akadályozzák a gyógyító munkát. A veszélyek fiziológiai sérelembe fordulása elleni védekezés a gyógyászat feladata, a veszélyek társadalmi következményeinek elhárítása közigazgatási hatáskör. „A közigazgatásnak meg kell küzdenie különféle veszélyekkel és veszélyhelyzetekkel, minimalizálni kell különféle veszélyek bekövetkezésének kockázatát... Veszélyt, veszélyhelyzetet számtalan körülmény idézhet elő (például természeti erő vagy emberi magatartás), de a közigazgatási jogban a veszély szinte mindig kapcsolódik az emberhez, az emberi tevékenységhez." (Fábián 2021: 197) A veszélynek ezt a tulajdonságát nevezzük társadalmi kockázatnak. „Társadalmi a kockázat attól lesz, hogy a veszély létrehozója emberi magatartás, továbbá, hogy a veszéllyel fenyegetett értékek a társadalom által elismertek, megvédelmezésük nélkül magának a társadalomnak a léte kerülhet veszélybe... A kockázat társadalmiságán mit sem változtat az, ha a jövőben fenyegető veszélynek kizárólag természeti forrása van, ami emberi közrehatás nélkül is elindít veszteségekhez vezetó oksági folyamatokat. Az ilyen kockázat azáltal válik társadalmivá, hogy az emberi létre jelent veszélyt, és elhárításának esélyei nagyban függenek a természetról szerzett ismeretek színvonalától, a társadalom felkészültségétől és szervezettségétől, és a kockázatokra adott válasz megválasztásának minőségétôl. (Az emberek nélküli világban sem a kockázat, sem a veszély, sem pedig a választás nem értelmezhető fogalmak.)" (Finszter 2019: 934)

Egy másik megközelítés, amit „reflexív modernizációnak" neveznek, azt a folyamatot kíséri figyelemmel, ahogyan a kezdetben nagy kockázatú tevékenység a technológia fejlődésével egyre biztonságosabbá válik (Bukovics-Kiss 2004). A modern kor legjelentősebb sike- reit azzal éri el, hogy a technikai védekező mechanizmusok egész rendszerét alakítja ki, és ez által azok a tényezők, amelyek kezdetben a kockázatokat növelték, a védekezés eszközeinek a megteremtéséhez is hozzájárulhatnak. Elsősorban a természettudományok eredményeinek köszönhetjük, hogy az emberiség a legnagyobb fenyegetéssel szemben sem marad fegyvertelen. Ezt hangsúlyozta a Magyar Tudományos Akadémia elnöke: „Az olyan válsághelyzetekben, mint amilyen a mostani is, nélkülözhetetlen a tudományos szakértők és a végrehajtó hatalom közötti hatékony együttmúk ödés. Ilyenkor a tudományos szakértelmet felkért személyek és ad hoc felállított testületek tudják a leginkább rendelkezésre bocsátani. Az Akadémiának és a tudományos múhelyeknek, intézeteknek, egyetemeknek a hátországot kell biztosítaniuk a számukra. Az összetett, számos tudományterület közremúködését igénylő, hosszútávon meghatározó kérdésekben pedig az állandó testületeké, akadémiáké a fó szerep."14

Ehhez azonban igazságkereső társadalmi berendezkedésre van szükség, olyan államhatalomra, amelyik nem hiszi, hogy az egyedüli igazság birtokában van, és olyan jogalkotásra, ami jogalkotót is köti. Az állam rendkívüli helyzetben történő múködésének fó eszköze a különleges jogrend.

\section{A különleges jogrend}

Magyarország Alaptörvényének 54. cikk 1-5. bekezdése a különleges jogrendről a következőket rendeli:

„Különleges jogrendben az alapvető jogok gyakorlása - a II. és a III. cikkben, valamint a XXVIII. cikk (2)-(6) bekezdésében megállapított alapvetô jogok kivételével felfüggeszthető vagy az I. cikk (3) bekezdése szerinti mértéken túl korlátozható.

Különleges jogrendben az Alaptörvény alkalmazása nem függeszthető fel, az Alkotmánybíróság múködése nem korlátozható. Különleges jogrend idején az Alkotmánybíróság múködése nem korlátozható. A Kormány különleges jogrendben köteles minden olyan intézkedést megtenni, amely az Alkotmánybíróság folyamatos múködését szavatolja.

A különleges jogrendet a különleges jogrend bevezetésére jogosult szerv megszünteti, ha kihirdetésének feltételei már nem állnak fenn.

A különleges jogrendben alkalmazandó részletes szabályokat sarkalatos törvény határozza meg." (Alaptörvény 54 . cikk $1-5$. bekezdés)

Ez idő szerint a különleges jogrendben bevezethetó intézkedésekről a Magyar Honvédségről szóló 2011. évi CXIII. törvény rendelkezik. Ezt a megoldást indokolt kritika éri: „Kiemelendő e körben, hogy sem rendszer-

${ }^{14}$ https://mta.hu/data/dokumentumok/egyeb_dokumentumok/2021/ MTU-brosura-2020-PRESS-4_Vegleges_dec_03.pdf. 
szintű, átfogó szemléletű védelmi és biztonsági törvényünk, sem egységes különleges jogrendi törvényünk nincs, mivel utóbbi tárgykört a katasztrófavédelemi és a honvédelmi törvény külön szabályozza. Ez utóbbi hiányosság, illetve megosztottság meglátásom szerint mindenképp orvosolandó egy olyan törvény megalkotásával, ami a védelmi és biztonsági feladatok ellátásának kormányzati koordinációját, egy nemzeti riasztási rendszer kereteit, az egyes ágazatokon túlmutató válságkezelés szabályait, a különleges jogrendi részletszabályozást, valamint mindezek felkészülési feladatait, ellenőrzését és begyakorlását egységesen, koherens és az ágazati törvények által hivatkozható módon biztosítaná." (Farkas 2020: 17)

A különleges jogrendben az alapvető jogok gyakorlása korlátozható, kivéve az élethez, az emberi méltósághoz való jogot, a tisztességes bírósági eljáráshoz való jogot, nem oldható fel a kegyetlen, embertelen bánásmód tilalma és az emberen végzett kísérletek tilalma.

\section{A különleges jogrend alkotmányossága}

„A különleges jogrend nem értelmezhető jogállamon kívül, hiszen ahol az állam múködése nem jogállami, ott a jognak való alávetettség, az állammúködés szabályok közé szorítottsága nem létező alapkövetelmény, így az azoktól való kivételes eltérés sem értelmezhető. Nem véletlen, hogy a jogi kategória ebben az értelemben az abszolutizmus időszakában még nem létezett, a totalitárius diktatúrákban pedig csupán a látszat alkotmányosság és törvényesség nagyszínpadának egy kelléke volt.” (Farkas 2020: 17)

Magyarország kormánya a COVID-19 fertőzés leküzdésére a 40/2020. (III. 11.) kormányrendeletben - az Alaptörvény 53. cikke szerinti veszélyhelyzetre figyelemmel - kihirdette a különleges jogrendet. Az 53. cikk a következőket tartalmazza: A Kormány az élet- és vagyonbiztonságot veszélyeztető elemi csapás vagy ipari szerencsétlenség esetén, valamint ezek következményeinek az elhárítása érdekében veszélyhelyzetet hirdet ki, és sarkalatos törvényben meghatározott rendkívüli intézkedéseket vezethet be... Különleges jogrend bevezetésére még további öt esetben van lehetőség, ezek a következők: a rendkívüli állapot; a szükségállapot; a megelőző védelmi helyzet; a terrorveszély-helyzet; a váratlan támadás. Igazat kell adni azoknak a kritikáknak, amelyek a veszélyhelyzet definíciójába nem tartják beilleszthetőnek a járványveszélyt, minthogy az nem elemi csapás (Gárdos-Orosz-Pap 2021: 584). A különleges jogrend bevezetésének jelenleg hatályos egyik alaptörvényi feltétele sem terjeszthető ki a járványveszélyre. Ez a helyzet változni fog 2023-tól, amikor a veszélyhelyzet új definíciója életbe lép: „A Kormány az élet- és vagyonbiztonságot veszélyeztető súlyos esemény - különösen elemi csapás vagy ipari szerencsétlenség - esetén, valamint ezek következ- ményeinek az elhárítása érdekében veszélyhelyzetet hirdethet ki. (2) A veszélyhelyzet harminc napra hirdethető ki. A Kormány a veszélyhelyzetet az Országgyúlés felhatalmazása alapján meghosszabbíthatja, ha a veszélyhelyzet kihirdetésére okot adó körülmény továbbra is fennáll.” (Módosított Alaptörvény 51. cikk (1)-(3) bekezdések.) A járványveszély minden további nélkül a „súlyos esemény” fogalma alá vonható. Más kérdés, hogy ez a fogalmazás, ami a különleges jogrend bevezetése előtt szinte korlátlan lehetőséget nyit, mennyire felel meg a jogbiztonság követelményének, és vajon az Alaptörvénytől is megkövetelhetö-e a jogkövetkezmények előreláthatóságát biztosító világos jogfogalmak használata?

A kritikusok arra is rámutatnak, hogy a világjárvány kezelésében a katasztrófavédelmi törvény a világjárvány elleni küzdelemben is hatékony eszköz a kormány kezében. A katasztrófavédelemról és a hozzá kapcsolódó egyes törvények módosításáról szóló 2011. évi CXXVIII. törvény (továbbiakban Kat. tv.) a katasztrófát úgy határozza meg, hogy a definíció a világjárványt is magába foglalja: „Katasztrófa: a veszélyhelyzet kihirdetésére alkalmas, illetve e helyzet kihirdetését el nem érő mértékű olyan állapot vagy helyzet, amely emberek életét, egészségét, anyagi értékeiket, a lakosság alapvető ellátását, a természeti környezetet, a természeti értékeket olyan módon vagy mértékben veszélyezteti, károsítja, hogy a kár megelőzése, elhárítása vagy a következmények felszámolása meghaladja az erre rendelt szervezetek előírt együttmúködési rendben történő védekezési lehetőségeit, és különleges intézkedések bevezetését, valamint az önkormányzatok és az állami szervek folyamatos és szigorúan összehangolt együttmúködését, illetve nemzetközi segítség igénybevételét igényli." (Kat. tv. 3. \$5 . pontja) Ezt az értelmezést tovább pontosítja a Kat. tv. 44 . \$ ca alpontja, ami a veszélyhelyzet fogalma alá vonja a tömeges megbetegedést okozó humánjárványt vagy járványveszélyt, valamint állatjárványt. A joguralom alkotmányosságát tanulmányozó vélemények sorában találunk olyan felfogást is, miszerint „a Kat. tv. alaptörvény-ellenes, ugyanis a járványveszély, mint veszélyhelyzet elrendelésére szolgáló indok nem jelenik meg az Alaptörvényben" (Balázs-Hoffman-Hungler 2021: 627). Ezt az ellentmondást a különleges jogrend 2023. VII. 01-től hatályos kilencedik módosítása megoldja, ha nem is a joguralom, hanem sokkal inkább az imperatív elmélet szellemében. „Az imperatív jogszemlélet azt tanítja, hogy jog ott van, ahol a legerősebb hatalom parancsai szükség esetén fizikai kényszerrel is kikényszeríttetnek. A legfőbb jogi szerv mögött ott állván a legerősebb hatalom, annak szava végső szó a jogban, amely ellen nincs jogorvoslat, amely tehát jogilag eo ipso csalhatatlan... Ahhoz, hogy jogról beszélhessünk, általános, elvont szabályok uralmára, a hatalommal szemben való érvényesülésére van szükség. Önkényes hatalmi parancsok uralma, a zsarnokság nem joguralom.” (Horváth 2001: 105) 
Alkotmányjogi kérdés, hogy „...lehetséges-e a veszélyhelyzet kihirdetése akkor, ha egyébként más speciális szabályok a jogrendben lehetôvé teszik a helyzet kezelését. Az egészségügyi törvény (az Egészségügyrôl szóló 1997. évi CLIV. törvény [továbbiakban Eütv.]) a katasztrófavédelmi törvény mellett számos lehetőséget kínált e tekintetben... A fentinél sokkal intenzívebben vitatott kérdés volt az az alkotmányjogban, hogy az április elsején kihirdetett, a koronavírus elleni védekezésről szóló törvény miként adott korlátlan felhatalmazást a kormány számára a vírus terjedésének megakadályozására és a hátrányos következményeinek enyhítésére vonatkozó rendeleti szabályok megalkotására, amikor az Alaptörvény szerint a felhatalmazás minden rendelet esetében 15 napig tart, amelyet az Országgyúlés meghosszabbíthat (A koronavírus elleni védekezésról szóló 2020. évi XII. törvény). A szakirodalom felhatalmazási törvénynek is nevezte ezt a jogszabályt..." (Gárdos-Orosz-Pap 2021: 585)

\section{Különleges jogrend a közigazgatásban}

A 2020. évi LVIII. törvény az Eütv. megfelelő módosításával megteremtette annak lehetőségét, hogy a közigazgatási jog a központi államigazgatás számára a korlátozó intézkedések egész tömegét alapozza meg.

„Az új törvényi szöveg a korábbiaknál jóval tágabb körben ad lehetőséget a közigazgatás beavatkozására, az abban foglalt intézkedések - így üzletek múködésének, nyitva tartásának szabályozása, utazási, közlekedési, áruszállítási korlátozások elrendelése, termékek árusításának, fogyasztásának korlátozása, köznevelési, szakképzési, felsőoktatási intézmények múködésével kapcsolatos szabályok bevezetése, a Magyar Honvédség bevonása a kórházak irányításába - jóval túlmutatnak az egészségügyi ellátórendszer sajátos járványügyi múködésének átalakításán." (Balázs-Hoffman-Hungler 2021: 628)

A különleges jogrend nem nélkülözheti a hatósági eljárásoknak a rendkívüli helyzethez alkalmazkodó rendjét. A hazai jogalkotás azonban széles körben hozott olyan változásokat, amelyek hosszabb távon is beépülnek a közjogba. „Ezek az eljárási korlátozások különösen a járványügyi helyzetben jelenhetnek meg, hiszen az emberek közötti érintkezések számának csökkentése szükségszerúen kihat az eljárási cselekményekre is. Amennyiben a járványügyi intézkedések közigazgatási hatósági eljárásokra gyakorolt hatására tekintünk, kiemelhetjük, hogy bár az érintkezések számának csökkentésével kapcsolatos kérdések is megjelentek az eljárásjogban, a hangsúlyosabbak a gazdasági közigazgatáshoz kapcsolódó változtatások voltak. A magyarországi megoldás sajátossága volt, hogy a foglalkoztatáspolitikai és a szociális ellátásokkal összefüggő eljárásokban viszonylag szúk körben alkalmaztak kivételeket, azaz ezek az eljárások elsődlegesen az általános szabályok között zajlottak továbbra is." (Balázs-Hoffman-Hungler 2021: 628)
Az önkormányzati rendszert a különleges jogrend ellentmondásosan érintette. Egyfelól a járvány idején indokolt a központi államigazgatás megerősítése, a centralizáció növekedése, másfelől azonban megjelentek olyan jogintézmények, amelyek a járványüggyel semmiféle öszszefüggést nem mutatnak, mint például a különleges gazdasági övezet, másfelől pedig a járvány elleni védekezésben nagyon is fontos kérdések, nehezen magyarázható módon, nem kerültek centralizálásra. Az önkormányzati rendszer koncentrációja és a centralizáció is megjelent a kormányzati intézkedések között. A $135 / 2020$. (IV. 17.) Korm. rendelet egy sajátos új jogintézményt teremtett, a gazdaság fejlesztését és munkahelyteremtést szolgáló beruházások esetében a különleges gazdasági övezetet. Mivel ez a rendelkezés csak a veszélyhelyzet időtartamára vonatkozott, s számos kérdés merült fel, hogy mi a teendő az elvont vagyonnal és bevételekkel a veszélyhelyzet megszúnése után, így a veszélyhelyzet megszüntetéséhez közeledve a fenti szabályrendszert is - egy sarkalatos rendelkezéséket is tartalmazó - törvénnyel a rendes jogrendszer kereteibe illesztették (2020. évi LIX. törvény). Ez azonban azt a látszatot kelti, mintha a veszélyhelyzeti gazdaságvédelmi indok csupán aktuálpolitikai indok egy újabb, az önkormányzatiságot érintő centralizációra. A helyzet ugyanakkor nem ilyen egyszerü, mivel nem feledhető az, hogy itt nem centralizációról van szó, mivel nem a központi államigazgatáshoz vagy annak valamely középszintû́ hivatalához kerültek helyi önkormányzati hatáskörök és tulajdon, hanem területi önkormányzatokhoz. Ezzel önmagában a decentralizáció elve nem sérült, csupán a területi szintje változott, és legfeljebb a szubszidiaritás elvének érvényesülése kérhetố számon. A centralizációs folyamatok mellett azonban ellenirányú mozgások is megjelentek a magyar közigazgatási jogban. A kijárási korlátozás meghosszabbításáról szóló 95/2020. (IV. 9.) Korm. rendelet például a húsvéti ünnepek időtartamára (2020. április 10-14.) kifejezetten lehetővé tette a települési önkormányzatok veszélyhelyzeti hatáskörében eljáró polgármestereinek, hogy helyi rendeletben hozzanak korlátozó intézkedéseket (Balázs-Hoffman-Hungler 2021: 630-631).

\section{A különleges jogrend és a büntető anyagi és eljárási jog}

„A felhatalmazási törvény (A koronavírus elleni védekezésről szóló 2020. évi XII. törvény) két új tényállással egészítette ki a Btk.-t. A járványügyi védekezés akadályozása (Btk. 322/A. \$) elnevezésú büncselekmény a közbiztonság fokozott védelmét kívánja biztosítani a hatóságok járványügyi intézkedéseit akadályozó cselekményekkel szemben. Az új tényállás alapján büntethetővé vált a »járványügyi elkülönítés, megfigyelés, zárlat vagy ellenőrzés" végrehajtásának akadályozása, amely a »zárlati kötelezettség alá tartozó fertőző betegség behurcolásának vagy terjedésének megakadályozása végett« 
került elrendelésre. Ugyanígy büntetendővé vált az a személy, aki a cselekményt fertőző betegség által okozott járvány idején követi el. Az új tényállás járványügyi védekezésben betöltött jelentőségét jelzi, hogy már a büncselekmény előkészülete is önállóan büntetendő. A járványügyi védekezés akadályozása bűncselekményként történő meghatározása logikus és érthető lépésnek tekinthető. Szakmai vitára adott okot ugyanakkor a Btk. 361. \$-ában meghatározott járványügyi szabályszegés büncselekmény dekriminalizációja ${ }^{15}$, ha azt a koronavírus-fertőzöttség vagy annak gyanúja miatt elrendelt járványügyi elkülönítés, megfigyelés, zárlat vagy ellenőrzés szabályainak megszegésével követik el." (Póczik et. al. 2021: 378)

Természetesen a járványveszély idején egyes hagyományos büncselekmények megvalósulása is kapcsolatban lehet a pandémiás szituációkkal. Ilyen példa lehet a testi sértés. „Ami azonban a befejezett testi sértésnek a COVID-19 átadása esetére való megállapítását a gyakorlatban igencsak megnehezíti, az az okozati összefüggés meglétének a megállapítása, tehát bizonyításának a problémája. E vírus ugyanis alapvetően cseppfertőzés útján terjed, így tüsszentés, köhögés útján közvetlenül vagy közvetve - például egy levegőben úszó porszemre ragadva - kerülhet mások szervezetébe, belehelés útján. Ennek egy büntetőeljárás keretében történő utólagos rekonstruálása ugyanakkor tetemes nehézséget jelenthet, hiszen ha a sértett nem csupán például a házi karantént engedély nélkül elhagyó, a koronavírust részére átadni szándékozó elkövetővel, hanem mással is találkozott a vádbeli időszakban, rögtön felmerülhet, hogy a vírust valójában nem is az elkövetőtől, hanem mástól kapta el." (Ambrus-Hollán 2021: 505-506)

A büntetô anyagi jog területét érinti a dekriminalizáció, ami az eljárások gyorsítását célozta. „A 181/2020. (V. 4.) Korm. rendelet egy új rendelkezést iktatott be a 81/2020. (IV. 1.) Korm. rendeletbe. Ennek alapján »nem büncselekmény, hanem szabálysértés valósul meg, ha a Btk. 36l. \$-ában meghatározott büncselekményt (járványügyi szabályszegést) a Covid19 fertőzöttség vagy annak gyanúja miatt elrendelt járványügyi elkülönítés, megfigyelés, zárlat vagy ellenőrzés szabályainak megszegésével követik el«. Ezt a szükségrendeleti szabályozást vette át (immár törvényi szinten) a veszélyhelyzet megszűnésével összefüggő átmeneti szabályokról és a járványügyi készültségről szóló 2020. évi LVIII. törvény (Vmt.). Az új szabályozás egyébként valójában nem átmeneti jellegü, a járványügyi szabályszegésról szóló rendelkezései ugyanis nem tartalmaznak olyan végső határidőt, ameddig azok érvényesülnek... A járványügyi szabályszegés dekriminalizációja helyes lépés volt, de azt

\footnotetext{
${ }^{15}$ A koronavírus elleni védekezésről szóló 2020. évi XII. törvény, a veszélyhely zet megszűnésével összefüggő átmeneti szabályokról és a járványügyi készültségről szóló 2020. évi LVIII. tv. 186. \$-a, továbbá az egészség és élet meg óvása, valamint a nemzetgazdaság helyreállítása érdekében elrendelt veszélyhelyzettel kapcsolatos rendkívüli intézkedésekról szóló 81/2020. (IV. 1.) kormányrendelet $5 . \$(2)$ bekezdés.
}

nem kellene a kiemelt járványügyi intézkedések megszegésének Covid19-fertőzéssel kapcsolatos eseteire korlátozni.” (Ambrus-Hollán 2021: 611-612)

Komoly vitákat váltott ki a rémhírterjesztés törvényi tényállásának a járvány idején történt módosítása. „A büncselekménynek a törvényhozás által módosított alapesete úgy szól, hogy aki közveszély színhelyén nagy nyilvánosság elött a közveszéllyel összefüggésben olyan valótlan tényt vagy való tényt oly módon elferdítve állít vagy híresztel, amely a közveszély színhelyén alkalmas az emberek nagyobb csoportjában zavar vagy nyugtalanság keltésére, büntett miatt három évig terjedő szabadságvesztéssel büntetendő.” (Bencze-Györy 2021: 617) A szerzők rámutatnak arra, hogy a tényállás alkalmazását a járványveszéllyel összefüggésben a közveszély színhelyén fordulat tesz problematikussá. Gondolataikat a következőkkel zárják: „Nem abban látjuk a problémát, hogy a jogalkotó egy bizonytalan ideig elhúzódó, az ország egész lakosságát fenyegető járvány megállítása érdekében változtatja és szigorítja a Btk. rendelkezéseit, hanem ennek a módjában. Ahogy itt kifejtettük, a rémhírterjesztés tényállására szerintünk már a járvány előtt is ráfért egy tisztázó módosítás. Az új törvényi feltételek sem az állampolgár (és az őket informáló újságírók) számára, sem a jogalkalmazók számára nem egyértelmúek. Olyan kérdésekben kellene előre állást foglalniuk, amelyekről a járványügyi és más szakemberek is vitáznak. A fenti példák és adatok alapján nem bizonyultak alaptalannak azok a vélemények, amelyek a szólásszabadság »önkéntes«, de aránytalan korlátozására (»chilling effect «, azaz »dermesztő hatás «) mint a szabályozás következményére hívják fel a figyelmet. Ugyanakkor látható, hogy a tényállás különleges jogrend esetén alkalmazható második bekezdése az oltás- és maszkellenesekre nem gyakorolt különösebb visszatartó hatást. A címzettek dolgát az könnyítené meg, ha a módosított és kiegészített törvényi tényállás - szakítva az eddigi hagyományokkal - a lehető legrészletesebb lenne, és pontosan körülírnák azokat az esetköröket, amelyek megvalósítják a cselekményt.” (Bencze-Gyôry 2021: 617)

A világjárvány kriminológiai hatásai körében az oksági háttér átrendeződése a bűnözés egészére is hatást gyakorolhat, de egyes deliktumok esetén, és ilyen a kábítószerbűnözés, különösen veszélyes tendenciák figyelhetőek meg. A téma szakértő kutatója, Ritter Ildikó a következőkre hívja fel a figyelmet: „A koronavírus okozta válság és gazdasági visszaesés továbbra is összetett kábítószerveszélyekkel fenyeget... Eszerint prognosztizálható, hogy - a határzár és a járványhoz kapcsolódó egyéb intézkedések droghiányt okoznak az utcán, ami magasabb árakhoz és csökkent tisztasághoz vezet...;

- a növekvô munkanélküliség és a lehetőségek hiánya növeli annak esélyét, hogy a szegény és deprivált emberek a kábítószerekhez vagy az ahhoz kapcsolódó tiltott tevékenységekhez fordulnak...” (Ritter 2020: 35)

A jelzett tendenciák a bűnüldözés számára új irányokat és módszereket szabhatnak a felderítésben, amelyek 
törvényes kereteit a különleges jogrendben érvényesülő eljárási szabályok teremtik meg.

A veszélyhelyzet ideje alatt érvényesülő egyes eljárásjogi intézkedésekről szóló 74/2020. (III. 31.) Korm. rendelet érinti a büntetőeljárás rendjét.

„A Rendelet 44. \$-a értelmében a Be. rendelkezéseit a Rendeletben foglalt eltérésekkel kell alkalmazni. Tekintettel arra, hogy az új koronavírus miatti veszélyhelyzet jelentősen megnehezíti a büntetőeljárásban való személyes részvételt, a Rendelet elsősorban a hatóságok és a résztvevők részéről is a minimálisra csökkenti a kötelező részvétel szabályait. A hatóságok részéról ilyennek kell tekinteni, hogy a 45 . $\$$ szerint az elsőfokú bíróság a büntetőeljárás során mindig egyesbíróként jár el (azaz első fokon nincs tanács) a veszélyhelyzet alatt.

A résztvevők közül pedig idesorolhatjuk például azt a szabályt, hogy a helyettes védőre vonatkozó korlátozó rendelkezésektől el lehet tekinteni (többek között a helyettes védő a nyomban egymást követő eljárási cselekményeken mindaddig eljárhat, amíg a kirendelt védő akadályozva van; a bizonyítási eljárás helyettes védővel is befejezhető, sőt a helyettes védő perbeszédet is tarthat).

A veszélyhelyzetre vonatkozó egyéb jogszabályokkal összhangban a Rendelet 48 . $\$$-a szerint külön döntés nélkül különleges bánásmódot igénylő személynek minősül a hatvanötödik életévét betöltött személy is (hiszen az ő mozgását az új koronavírus alatt érvényben lévő szabályok korlátozzák). Az eljárási cselekményeken való részvételi kötelezettség csökkentésének egyik fó módja a Rendelet szerint a telekommunikációs eszközökön keresztüli kapcsolattartás elősegítése... Szintén a személyes részvétel mellőzését segíti elő, hogy a 49 . $\$$ szerint a bíróság mellőzheti a tanú kihallgatását, ha bármelyik hatóság korábban a kihallgatásáról kép- és hangfelvételt vagy hangfelvételt készített.

Bizonyos eljárási cselekmények elvégezhetők a veszélyhelyzet idején is. Ugyanakkor vannak olyan résztvevők (de akár a hatóság tagja is kerülhet ilyen helyzetbe), akik nem tudnak részt venni az eljárási cselekményeken az elrendelt járványügyi elkülönítés, megfigyelés, zárlat vagy ellenőrzés szabályainak megszegése nélkül. Ilyenkor föszabályként a hatóságnak el kell halasztania az eljárási cselekmény elvégzését (50. \$ (1) bekezdés). Ha erre a halasztásra nincs mód, akkor az eljárási cselekményen való jelenlétet telekommunikációs eszköz útján kell biztosítani...

Mivel a veszélyhelyzet megnehezíti nemcsak a személyes kapcsolattartást, hanem a mindennapi életet is (például postára járás), az 52 . $\$$ (1) bekezdése szerint az ülésen közölt határozat elleni fellebbezésre nem három nap, hanem az üléstől számított öt munkanap áll rendelkezésre...

Több helyen is 15 napra nőtt a 8 napos jogorvoslati határidő (például az elektronikus adat feletti rendelkezésre jogosult fellebbezési határideje az elektronikus adathoz való hozzáférés ideiglenes megakadályozásával összefüggésben; a védőnek a gyanúsítás illetve annak vál- tozása elleni panaszjoga, a felülbírálati indítvány előterjesztésére nyitva álló határidő). Sőt a szakértőkkel szembeni szigorú határidők is jelentősen enyhültek, hiszen a szakvélemény előterjesztésére nyitva álló két hónapos, egy alkalommal, egy hónappal meghosszabbítható határidő a Rendelet 62 . $\$$-a szerint több alkalommal, alkalmanként legfeljebb három hónappal meghosszabbítható.” (Herke-Sándor 2020: 7-8)

A különleges jogrendnek a büntetőeljárások szabályozására gyakorolt hatása már átvezet a rendészet területére.

\section{A különleges jogrend és a rendészeti igazgatás}

A világjárvány veszélyt jelent a Föld minden lakójára. A rendészeti igazgatás veszélyelhárító funkciókat teljesít. Járványról hallva mégsem a rendőr, hanem az orvos jut eszünkbe. És ez így van rendjén. A rendészeti veszélynek megkülönböztető tulajdonsága, hogy annak hátterében mindig megtaláljuk a jogellenes emberi magatartást. Ettôl válik a veszély rendészeti üggyé. Ez idáig a rendészettudomány külföldi és hazai múvelői a veszély két formáját írták le, a rendészeti és a katonai változatokat. A katona és a rendőr mesterségének egyaránt az a különleges küldetése, hogy szakmai tudásuk képessé teszi e testületek tagjait a fenyegetések felismerésére és azok fizikai erőhatalommal történő elhárítására (Huntington 1994).

A világjárvány előidézte helyzet nem sorolható sem a rendészeti, sem a katonai veszélyhelyzethez. Forrása nem jogellenesség, megoldása nem a legitim erőszak bevetése. A veszély helye nem lokális, mint a rendészeti veszély esetében, de nem is frontvonalakkal leírható, mint a legtöbb katonai konfliktus. A pandémia helye a nagyvilág. A veszély kezdete csak vélelmezhető, idôtartama matematikai módszerekkel becsülhető meg és kizárólag a természettudományok segítségével rövidíthető meg. (Nem köthető a jog által meghatározott határidőkhöz, nem maradhat felderítetlenül, de nem is remélhetjük a vírus feltétel nélküli kapitulációját.) A veszélyelhárítás eszköze nem lehet sem a rendészeti legitim fizikai erőszak, sem a katonai erő.

Mégis igaz, hogy - noha eltérő mértékben és módon a világ valamennyi járvány sújtotta kormánya nem nélkülözheti sem a rendészet, sem a katonaság közremúködését. Ennek oka elsődlegesen a világjárvány keltette veszélyhelyzetnek az a jellemzője, hogy abban nem különíthető el a belső és a külső kockázat. Amint azt a világjárvány egyediségének bemutatásánál írtuk, a kihívás totális, amiben „...mindenki belsőként érintett. A rendkívüli helyzetre elóírt rendszabályok - a karanténtól a maszkviselésen át egészen a kijárási tilalomig - mindenkire érvényesek." A hétköznapi élet gyökeresen megváltozik. Ami nyugalmas időkben a polgári lét természetes része volt, a veszély idején szigorúan tiltott magatartás 
lesz. Olyan próbatétel ez, ami kitágítja a jogsértések körét, és ezek megelözése, a rend feletti őrködés, valamint a számonkérés meghaladja a rendelkezésre álló rendészeti erők kapacitását, esetleg még katonai közremúködést is szükségessé tehet. Ezzel a lehetőséggel az Alaptörvény is számol, amikor a honvédség igénybevételét a szükségállapotra szúkíti. „A Magyar Honvédséget szükségállapot idején akkor lehet felhasználni, ha a rendőrség és a nemzetbiztonsági szolgálatok alkalmazása nem elegendő.” (Alaptörvény 50. cikk (1) bekezdés)

„A szükségállapot különleges jogrend időszakában sem kizárt az ország fegyveres erejének felhasználása a szükségállapot tényállásában megjelölt helyzet kezelésére. Az Alaptörvény alkotmányos garanciális szabályai szerint azonban a Magyar Honvédséget szükségállapot idején csak akkor lehet felhasználni, ha a rendőrség és a nemzetbiztonsági szolgálatok alkalmazása a kialakult helyzet kezelésére nem elegendő. Szükségállapot idején az Országgyúlés - akadályoztatása esetén a köztársasági elnök - dönt a Magyar Honvédség ez irányú felhasználásáról." (Lakatos 2014: 6)

A jelenlegi jogi helyzet tehát az, hogy az Alaptörvény csak a szülkségállapot okán elrendelt különleges jogrendben teszi lehetővé a Magyar Honvédség igénybevételét. Alaptörvény már korábban jelzett kilencedik módosítása 2023. július 1-tôl ezt az akadályt is elhárítja, minthogy a szükségállapot meghatározásából elhagyja a katonaság igénybevételét feltételhez kötő fordulatot.

A rendészeti erők hazai bevetésének rendészetelméleti értékelésének még nem jött el az ideje. Erre a posztCOVID időkben is csak akkor nyílik majd lehetőség, ha a kormányzat kíváncsi lesz saját teljesítménye tudományos értékelésére. A nyilvánosság számára elérhető információk alapján addig is tehető néhány megállapítás. „A poszt-COVID-jelenségek vizsgálatára hirdet pályázatot az MTA Napról-napra jobban ismerjük, de még mindig nem eléggé. A koronavírus nem csupán közvetlen veszélyt jelent az emberre, de hosszú távon is hatással lehet testi és lelki egészségünkre. Legalább ilyen fontos az is, hogy tisztában legyünk az általa okozott járvány társadalmi-gazdasági hatásaival. Ezért hirdette meg »Post-COVID pályázat 2021 « címmel úgynevezett nagy kockázatú pályázatát. Erre olyan kutatók jelentkezését várják, akik a koronavírus-járvány okozta egészségügyi, társadalmi, kulturális problémák feltárására és megoldására adhatnak válaszokat."16

A Koronavírus-járvány Elleni Védekezésért Felelős Operatív Törzs felállításáról szóló 1012/2020. (I. 31.) Korm. határozat jól mutatja a rendészeti igazgatás hangsúlyos szerepét.

„A Kormány Koronavírus-járvány Elleni Védekezésért Felelős Operatív Törzset (a továbbiakban: Operatív Törzs) tagjának a belügyminisztert, a Belügyminisztéri-

${ }^{16}$ https://mta.hu/mta_hirei/a-post-covid-jelensegek-vizsgalatara-hirdetpalyazatot-az-mta-111493. um közbiztonsági főigazgatóját és az országos rendőrfőkapitányt, az Országos Idegenrendészeti Főigazgatóság főigazgatóját, az Országos Katasztrófavédelmi Főigazgatóság fóigazgatóját és a Terrorelhárítási Információs és Bünügyi Elemző Központ főigazgatóját. Az Operatív Törzs ülésén részt vesznek továbbá a belügyminiszter által erre felkért személyek."

Az élet- és vagyonbiztonságot veszélyeztető tömeges megbetegedést okozó humánjárvány megelőzése, illetve következményeinek elhárítása, a magyar állampolgárok egészségének és életének megóvása érdekében elrendelt veszélyhelyzet során teendő intézkedésekről szóló 41/2020. (III. 11.) Korm. rendelet feladatot rótt a rendészeti igazgatásra:

„cb) a hatósági házi karanténra vonatkozó szabályok betartását az általános rendőrségi feladatok ellátására létrehozott szerv (a továbbiakban: rendőrség) ellenőrzi,

d) a rendvédelmi feladatokat ellátó szervek hivatásos állományának szolgálati jogviszonyáról szóló 2015. évi XLII. törvény szerinti hivatásos szolgálati jogviszonyban álók és rendvédelmi igazgatási alkalmazottak... Magyarország területét csak az ágazat irányításáért felelős miniszter külön engedélyével hagyhatják el.”

A járványveszélyben megsokasodott rendőri feladatok kettős terhelést jelentettek az állomány számára. Egyfelől maga a szolgálatellátással összefüggő feladatok jelentettek újszerú, addig nem tapasztalt kihívásokat, másfelől a fokozottan fertőzésveszélyes környezetben történő végrehajtás megnövelte a saját és a szúkebb családi környezett megfertőződéséért érzett aggodalmat. A témakör kutatója Borbély Zsuzsanna tanulmányában - egyebek mellett - európai példákkal is szolgál: „Frenkel és munkatársai kutatása kifejezetten az európai rendőrökre koncentrált a Covid-19 tavaszi időszakában, longitudinális vizsgálatban. Hat európai ország rendőri körében zajlott a vizsgálat: Ausztria, Németország, Svájc, Hollandia és Spanyolország baszk régiója. Eredményeik több érdekességet is tartogattak. Azon kevesek körében, akik beszámoltak a magánéleti stresszorokról, alapvetően a hozzátartozókért való aggodalom és az online oktatás miatt otthonról tanuló gyerekek felügyelete okozta a stresszt. A főbb rendőri feladatok ebben az időszakban a megszokottak mellett a koronavírushoz kapcsolódó rendőri tevékenységek voltak. A munkahelyi stressz megtapasztalása a járványhoz kapcsolódóan nagyon vegyes képet mutatott: a válaszadók mintegy negyede nem vett észre változást ezen a téren, ugyanakkor a fertőzéshez kapcsolódó félelmek közül ebben a kutatásban is több aspektus megmutatkozott: a fertőzötté válástól való félelem, illetve a mások megfertőzésére irányuló aggodalmak.” (Borbély 2021b: 14-15) Hasonló megállapításokra jutott a szerző a próbaidős tiszthelyettesek körében végzett hazai vizsgálata. 
A kórházparancsnokról és az egészségügyi készlet védelméról szóló 72/2020. (III. 28.) Korm. rendelet a következőket írta elő:

„1. $\$$ A fekvőbeteg szakellátást, illetve a fekvóbeteg szakellátáshoz kapcsolódó járóbeteg szakellátást nyújtó egészségügyi intézmény (a továbbiakban: egészségügyi intézmény) fenntartója - a fenntartó személyétôl függetlenül - valamennyi telephelyén fokozott figyelemmel gondoskodik a koronavírus-járvány elleni védekezés érdekében a szükséges egészségügyi felszerelések, berendezések, gyógyszerkészletek és fertôtlenítőszerek (a továbbiakban együtt: egészségügyi készlet) megóvásáról.

2. $\$$ (1) A költségvetési forrásból beszerzett egészségügyi készletek felhasználásának ellenőrzésére a rendészetért felelős miniszter javaslatot tesz - szükség esetén a Koronavírus-járvány Elleni Védekezésért Felelős Operatív Törzs (a továbbiakban: Operatív Törzs) véleményének kikérését követően - az egészségügyi intézményhez kórházparancsnok kirendelésére.

(2) A kórházparancsnok részére a rendészetért felelős miniszter javaslatára a miniszterelnök megbízólevelet állít ki. A megbízólevél kiállítását követően a kórházparancsnokot az egészségügyi intézményhez a rendészetért felelős miniszter rendeli ki.

(3) A kórházparancsnok tevékenységét a rendészetért felelős miniszter - a 3. \$-ban meghatározottak szerint irányítja.

(4) A kórházparancsnoknak a járványveszéllyel összefüggő szabályok betartására, és az egészségügyi készlet megóvására vonatkozó javaslatát az egészségügyi intézmény vezetôje köteles végrehajtani.

(5) A kórházparancsnok orvosszakmai kérdésekben nem tehet javaslatot, és nem hozhat döntést.”

A 367/2021. (VI. 30.) Korm. rendelet a kórházparancsnoki és intézményparancsnoki feladatok ellátásának ideiglenes szüneteléséről határozott:

„A Kormány az egészségügyről szóló 1997. évi CLIV. törvény 247. $\$(\mathrm{lb})$ bekezdés $c)$ pontjában kapott felhatalmazás alapján, az Alaptörvény 15. cikk (1) bekezdésében meghatározott feladatkörében eljárva a következőket rendeli el:

1. \$ A kórházparancsnokról és az egészségügyi készlet védelméról szóló 72/2020. (III. 28.) Korm. rendelet, illetve az egészségügyi készlet állagának megóvása érdekében szükséges intézkedésekről szóló 287/2020. (VI. 17.) Korm. rendelet alapján megbízott és kirendelt országos kórház-fóparancsnok és országos kórházfőparancsnok-helyettes tevékenysége, valamint a kórházparancsnokok kórházparancsnoki és intézményparancsnoki tevékenysége 2021 . szeptember 15. napjáig szünetel.

2. $\$(1)$ Ez a rendelet a kihirdetését követő napon lép hatályba.
(2) Ez a rendelet 2021. szeptember 16-án hatályát veszti."

A kórházparancsnoki intézmény értékelése is a posztCOVID időkre marad.

A rendőrség számára több feladatot határoz meg a kijárási korlátozásról szóló 71/2020. (III. 27.) Korm. rendelet. Egyebek mellett a következó korlátozások bevezetésére került sor:

„1. $\$$ (1) Mindenki köteles más emberekkel a szociális érintkezést - a közös háztartásban élők kivételével - a lehető legkisebb mértékúre korlátozni, és a másik embertôl lehetőség szerint legalább 1,5 méter távolságot tartani.

(2) Az (1) bekezdést a tömegközlekedés során is alkalmazni kell.

2. $\$$ Vendéglátó üzletben - az ott foglalkoztatottak kivételével - tartózkodni tilos. Kivételt képez az elvitelre alkalmas ételek kiadása és szállítása.

3. \$ A lakóhely, a tartózkodási hely, illetve a magánlakás elhagyására az e rendeletben meghatározott alapos indokkal kerülhet sor."

A rendeletben a rendészeti feladatokról a következőket olvashatjuk:

„8. $\$(1)$ E rendelet szerinti korlátozó intézkedések betartását a rendőrség ellenőrzi, a katonai rendészet és a rendvédelmi feladatokat ellátó szervek hivatásos állományának szolgálati jogviszonyáról szóló törvény szerinti bármely szerv bevonásával.

(2) E rendelet szerinti korlátózó intézkedések be nem tartása esetén a rendőr a Rendőrségről szóló 1994. évi XXXIV. törvény (a továbbiakban: Rtv.) szerinti intézkedéseket és kényszerítő eszközöket a szükségesség és arányosság követelménye betartásával az Rtv.-ben meghatározott módon alkalmazhatja.

9. \$ (1) A szabálysértésekrôl, a szabálysértési eljárásról és a szabálysértési nyilvántartási rendszerről szóló 2012. évi II. törvény (a továbbiakban: Szabstv.) 1. $\$$ (1) bekezdésétől eltérően szabálysértést követ el, aki az e rendeletben meghatározott korlátozó intézkedést megszegi.

(2) A Szabstv. 11. \$ (1) bekezdésétől eltérően az (1) bekezdés szerinti szabálysértés esetén a pénzbírság legalacsonyabb összege ötezer forint, legmagasabb összege ötszázezer forint."

„A veszélyhelyzet bevezetésével megnyílt az út a rendeleti kormányzás elótt, amely lehetôvé tette a napról napra változó helyzethez igazodó gyors és hatékony jogalkotást. A védelmi intézkedéseknek érvényt kell szerezni, és ebben a feladatban a szabálysértési jogterület is jelentős szerephez jutott. A védelmi intézkedések közül azoknak a szankcionálására, amelyek megsértése veszélyt jelent a társadalomra - de ez a veszély a büntetőjogi felelősségre vonás szintjét nem éri el -, és amelyek megsértése felróható az elkövetők számára, szabálysértési jog a megfelelő eszköz." (Skorka 2021: 99) 
A hazai, de külföldi szakirodalom is különös figyelemmel követi a rendészeti beavatkozások jogszerúségét:

„A koronavírus és az ahhoz köthető intézkedésekkel valószínúleg leggyakrabban a diszkrimináció, más szóval a hátrányos megkülönböztetés tilalma, illetve pozitív értelemben az egyenlő bánásmód követelménye, mint alkotmányos alapjog merül fel... A járványügyi szabályok szankcionálása során is egyetemesnek tekinthető a fajietnikai kisebbségeket érintő kiemelt figyelem és sok esetben az erőszakosabb hatósági fellépés. A Black Lives Matter mozgalom előretörése Amerikában annak a jól dokumentált jelenségnek a következménye, hogy a meglévő, ez esetben faji-etnikai alapon konceptualizált társadalmi egyenlőtlenségeket (például a büntető-igazságszolgáltatási rendszerben, ezen belül kiemelten a rendészet terén) felerősítik a vírus és a járványügyi intézkedések.” (Gárdos-Orosz-Pap 2021: 587-588.)

Más megközelítésben tárgyalja a problémát az Egyesült Királyság két kutatója: „...ismertetik azokat a rendőri, rendészeti jellegű intézkedéseket, amelyekkel a társadalmi (egyéni, csoportos, tömeges) ellenállást javasolt kezelni... A közösségi konfliktusoknak, ellenállásnak nagy a bekövetkezési valószínűsége, ha a társadalom tagja úgy értékelik a helyzetüket, hogy az állam aránytalanul intézkedik... Amennyiben az ilyen intézkedéseknek a központi hatalom részéról, a társadalom valamennyi tagja és szereplője felé, objektív kommunikáció útján bemutatott indokoltsága van, azt elfogadóbban kezeli a kevéssé támogatott közösség is. Szintén hivatkoznak olyan eredményekre is, amelyek szerint a hiteles, objektív, teljes körü kommunikáció kiválthatja a társadalmi tagjai között az együttérzést, ami jellemzően önszabályozó, normakövető viselkedéssel is együtt jár. Ezek a reakciók a korlátozó intézkedések, a rendészeti szervek feladatellátásának támogatását is eredményezhetik, ami a »közülünk « és »értünk « gondolati megközelítéseként jelenhet meg..." (Éberhardt 2021a: 292)

„Kathryn Farrow kriminológus, doktorandusz, kutatási területe a rendőrségbe vetett bizalom kérdésköre. Írásában a koronavírus járvány elleni küzdelem rendészeti feladatait foglalja össze az eljárási igazságosság elvének fókuszba helyezésével. Példáit az Egyesült Királyságban megvalósult gyakorlatból meríti. Farrow hangsúlyozza, hogy a rendőrség szerepvállalásának egy közegészségügyi krízishelyzet megoldásában nincsenek előzményei, ugyanakkor világszerte számos kormány élt ezzel a megoldással. Felhívja a figyelmet arra is, hogy a korlátozások és karantén intézkedések betartatása feltételezi a szúkebb és a tágabb társadalmi közösségek együttmúködését a rendőrséggel. A helyzetet nehezíti, hogy az állampolgároknak nem volt módjuk közremüködni az új szabályok kialakításába, és nincs információjuk arról sem, hogy a rendkívüli körülmények meddig maradnak fenn.
Emellett a szerző összegyüjti azokat a fogalmakat, kifejezéseket, amelyek értelmezése és/vagy gyakorlati alkalmazása nehézségeket okozhat és okoz a vírushelyzet kapcsán a rendészeti tevékenységben: ésszerú gyanú és indokolható kivétel, méltányosság és eljárási igazságosság.

Az ésszerû gyanú fogalma azt takarja, amikor különböző tényezők okán a rendőrök gyanítják, hogy az intézkedés alá vont személy esetleg COVID-19 fertőzött lehet, s ennek megfelelően intézkednek vele szemben. Ugyanakkor nehézség, hogy mely tényezők azok, amelyek alapján a gyanú jogosnak tekinthető. Ehhez kapcsolódik az indokolható kivétel fogalma, amely még homályosabb, mert arra vonatkozik, hogy a kijárási korlátozások időszakában mi számít ésszerû indoknak otthonunk elhagyására. A szerző azt is jelzi, hogy a rendőri vezetés a cikk írása idején már megfogalmazott iránymutatásokat az említett fogalmak értelmezéséhez. Mindez arra mutat, hogy a jogbiztonság és a méltányosság követelménye a rendkívüli helyzetek kezelése során is követelmény marad.

Mindezekhez szorosan kapcsolódó fogalom a méltányosság, amely arra vonatkozik, hogy a rendőrök pártatlanul és igazságosan bánnak az emberekkel, kivételezés vagy diszkrimináció nélkül, s következetesek ebben. Az eljárási igazságosság pedig szervesen kapcsolódik ehhez, ugyanis a méltányosság ennek egy kulcsfontosságú eleme. Az eljárási igazságosság elve arra hívja fel a figyelmet, hogy a rendőri intézkedés alá vont állampolgárok jobban elfogadják annak kedvezőtlen következményeit is, ha a rendőrök eljárása részrehajlás mentes, következetes és mindenkire egyformán érvényesül. Vagyis az eljárási igazságosság érvényesülése, állampolgárok és a rendőrség közötti kommunikáció megfelelő minősége megerősítheti a társadalom rendőrségbe vetett bizalmát.

Farrow megemlít egy másik kulcsfontosságú tényezőt is, ez pedig az információ-megosztás. Hogy ez miért is ennyire fontos? Mert a nyitottságot, hajlandóságot közvetíti az állampolgárok felé, amely képes fokozni a szabályok betartására való készséget is.

Emellett hangsúlyozza, hogy az eljárási igazságosság elve nem csak az állampolgárokkal szemben, hanem a szervezeten belül is követelmény. Ebben a vonatkozásban az elv azt jelenti, hogy milyen mértékben lehetnek biztosak a szervezet tagjai abban, hogy mérlegelést igénylö szakszerú, elfogulatlan, következetes és transzparens döntéseik találkoznak szakmai vezetőik támogatásával. Ennek feltétele a szervezeten belüli információmegosztás, ami, ha átlátható és nyitott módon történik, segíti a rendőröket abban, hogy kompetensen, a legalitás jegyében képviseljék a szabályokat, és találják meg a legjobb megoldást még az esetlegesen adódó nehéz helyzetekben is." (Borbély 2021a: 286) 
„A COVID-19 járványra a tudományos közeg gyorsan reagált, az új típusú kihívások következtében, az annak hatásaival és kezelésével foglalkozó tanulmányok bőséggel állnak rendelkezésre. Mivel a világjárvány az élet szinte minden szegmensét érinti, számos tudományos igényű munka született rendészettudományi területen is.

A tanulmány témája a Brazil közrendőrök járványhelyzet alatti tevékenysége, a döntéshozatali mechanizmusaik jellemzői. Ennek alapja, hogy a rutin feladatok mellett jelentkeznek a vírushelyzet kezeléséhez kapcsolódó, új feladatok is, a rendszeresség és a korábbi tapasztalatok hiánya által a megoldásra váró helyzetekben nő az egyéni mérlegelés lehetősége. A szerzők feltételezése szerint az egyéni mérlegelési kényszer döntéshelyzetben feszültséget generálhat az utcákon szolgálatot teljesítő rendőrökben. A magas mérlegelési jogkör mellett a hiányos elszámoltathatóság szintén hatással van az extrém körülmények között meghozott válaszreakciók hatékonyságára." (Vizvári 2021: 301-302)

\section{A WHO erófeszítései, egy világjárványokról szóló nemzetközi szerződés gondolata}

Miközben az alkotmányosság követelménye minden kormánytól számonkérhető, amelyik hatalmát demokratikus jogállami módon gyakorolja, a következőkre is figyelemmel kell lenni: „A COVID-19 világjárvány világosan jelzi, hogy a globalizált világ mennyire kiszolgáltatott a fertőző betegségeknek. Ez felveti a kérdést, hogy az állam felelősségre vonható-e azért, ha nem hoz kellö időben hatékony intézkedéseket egy potenciálisan halálos kórokozó elterjedésének megakadályozására... Az államok felelőssége így legalább a következőkre terjed ki:

1. általánosan elfogadott célok elérése érdekében össze kell hangolniuk erőfeszítéseiket, és nem akadályozhatják mások erőfeszítéseit a fenyegetés visszaszorítására;

2. segítséget kell nyújtaniuk egymásnak a szükséges intézkedések terhei, például a gazdasági költségek megosztása érdekében, valamint a szúkös gyógyszerek, orvosi berendezések és - várhatóan rövidtávon - a védőoltások elérhetőségének globális összehangolása és optimális elosztása érdekében;

3. biztosítaniuk kell a transzparenciát, és nem akadályozhatják a járványügyi adatok nyilvános elérhetőségét;

4. meg kell tenniük mindent, amit képességeik és eróforrásaik lehetővé tesznek, hogy teszteljék és elkülönítsék területükön a fertőzött személyeket, és felderítsék a velük kapcsolatban állókat, akiket megfertőzhettek.

A fenti követelmények bármelyikének figyelmen kívül hagyása halálos következményláncolatok kialakulásához járulhat hozzá, például ki- és beutazó személyek, illetve más országok kormányainak és egészségügyi személyzetének felkészültségi deficitjén vagy éppen kulcsfontosságú gyógyszerek és orvosi berendezések hiányán vagy nem kielégítő mértékû elérhetőségén keresztül." (Hoffmann-Marton-Gruszczynski 2021: 596-597)

A pandémiás helyzet drámai megfogalmazását olvashatjuk az Európai Tanács 2021. március 30-i sajtóközleményében: „A COVID-19 világjárvány élesen és fájdalmasan emlékeztetett minket arra, hogy senki sincs biztonságban addig, amig nincs mindenki biztonságban. "17

A SARS-CoV-2-vírus által okozott pandémia - számos 20. és 21. századi esemény mellett természetesen - újabb lehetőség arra, hogy tapasztalatokat szerezzünk világunk globális cselekvőképességének aktuális státuszáról, ez esetben a WHO által a globális egészségbiztonság megteremtésének szempontjából vizsgálódva.

A globális cselekvőképesség alatt egy potenciálisan igazolt lehetséges valóságot értünk, amely azt fejezi ki, hogy egy átfogó kihívásra az emberiség az adott világrendet meghatározó hatalompolitikai viszonyok és együttmúködés rendszerében milyen koordinált aktivitást képes a társadalmi cselekvés gyakorlatába átültetni e kihívás átfogó és eredményes kezelése érdekében. Fontos, hogy a globális cselekvóképesség politikai realitás nélkül puszta utópia marad, még akkor is, ha tudjuk, hogy végső soron minden emberi megnyilvánulást egyetemes hatások követnek. A globális cselekvőképesség fontosságának felismerése a közelmúltban elhatározott nemzetközi szerzôdés gondolatáig vezetett.

A WHO-t az ENSZ hozta létre 1948-ban azzal a céllal, „hogy valamennyi nép a lehetö legmagasabb egészségügyi szinvonalat érje el”. Alkotmányát hazánkban az Egészségügyi Világszervezet Alkotmányának becikkelyezéséről szóló 1948. évi XII. törvény hirdette ki. Közgyülése jogosult a Szervezet hatáskörébe tartozó minden kérdésre vonatkozóan egyezményeket vagy megállapodásokat elfogadni (1948. évi XII. törvény 19. cikk), jogában áll szabályzatokat elfogadni többek között olyan egészségügyi intézkedés és vesztegzár vagy minden egyéb olyan eljárás tárgyában, amelynek célja a betegségek egyik országból a másikba átterjedésének megakadályozása. (1948. évi XII. törvény 21. cikk)

Ez utóbbi körben, a végrehajtásképp elfogadott szabályzatok - a tagállamokban történt elfogadást követően - kötelező érvényüek, kivéve, amennyiben az adott állam a meghatározott határidőben fenntartással él vagy nem fogadja el a rendelkezéseket (1948. évi XII. törvény 22. cikk).

A WHO az 1969-tôl hatályos Nemzetközi Egészségügyi Rendszabályok (International Health Regulations, a továbbiakban: IHR) felülvizsgálatát követően 2005-ben fo-

${ }^{17}$ https://www.consilium.europa.eu/hu/press/press-releases/2021/03/30/ pandemic-treaty-op-ed/. 
gadta el az új IHR-t (WHO 58.3 számú határozat), amely Magyarországon 2007. június 15-én lépett hatályba, kihirdetése pedig az Egészségügyi Világszervezet Nemzetközi Egészségügyi Rendszabályainak kihirdetéséről szóló 2009. évi XCI. törvényben (a továbbiakban IHR tv.) történt meg. (A WHO rendszabályt valamennyi EU tagállamok elfogadták, az USA és India fenntartást közölt.)

Az IHR egyik alapelve szerint a Rendszabályok végrebajtását a világ összes népének a betegségek nemzetközi terjedésével szembeni védelme érdekében történō egyetemes al kalmazásuk célja vezérli (IHR tv. 3. cikk 3. pontja).

A Rendszabályok megújítására azért került sor, mert az új évezred első évtizedében egy globális jelzố-és reagáló rendszer kiépitésére volt szükség a váratlan közegészségügyi-járványügyi szükséghelyzetek gyors és hatékony kezelésére. Alkalmazási köre pedig a betegségek nemzetközi terjedésének megakadályozása mellett kiterjed a védekezésre, a közegészségügyi-járványügyi reagálásra azzal, hogy intézkedéseivel a nemzetközi forgalmat és kereskedelmet szükségtelen módon nem zavarja (IHR tv. 2. cikk).

A nemzetközi szervezet tevékenységével párhuzamosan haladt a magyarországi felkészülés is. A 2001-ben átdolgozott első, 1997-es influenza pandémiás terv ismételt felülvizsgálatára előbb 2005-ben, majd 2009-ben került sor. Jelenleg ez utóbbi dokumentum a hatályos Nemzeti Influenza Pandémiás Terv (NIPT), amelynek készítésekor már támaszkodhattunk a WHO 2009 tavaszán aktualizált útmutatójára, ami az influenza világjárványra történő felkészülés érdekében szükséges intézkedések végrehajtását tartalmazza. Az EU valamennyi tagállama rendelkezik ilyen aktualizált pandémiás tervvel.

Megjegyezzük, hogy 2005-ben jelent meg az Európai Bizottság közleménye a közegészségügyi vészhelyzetek általános készültségi terveinek közösségi szinten történöösszehangolásáról, amelyet egy Általános készültségi tervezésre irányuló stratégia címú gyakorlati útmutató ${ }^{18}$ egészített ki, illetőleg megalakult az Európai Betegségmegelőzési és Járványügyi Központ (ECDC) is. (Az Európai Parlament és a Tanács 851/2004/EK Rendelete [2004. április 21.] ${ }^{19}$; A HlNl-járvány tapasztalataira is figyelemmel a készültségi tervek átdolgozása és kiadása 2009. év végén megtörtént. ${ }^{20}$ A COVID-19 kapcsán nemcsak globálisan, de kisebb szerveződési szinteken is adósok maradtunk egy ilyen kibivás kezelését segitô" komplex, összehangolt megoldással. Nem ez volt az első eset. A 2009-es HlNl-járvány tapasztalatait összegezve az IHR Felülvizsgálati Bizottsága úgy foglalt állást, hogy „a világ nincs felkészülve egy súlyos influenzajárványra, vagy bármilyen hasonló globális, tartós és fenyegető közegészségügyi vészhelyzetre történo" reagálásra” (https://www.euro.

\footnotetext{
${ }^{18}$ https://eur-lex.europa.eu/legal-content/hu/TXT/?uri=CELEX\%3A52005DC0607. ${ }^{19}$ https://eur-lex.europa.eu/legal-content/HU/TXT/PDF/?uri=CELEX:320 04R0851\&from $=\mathrm{HU}$.

${ }^{20}$ https://eur-lex.europa.eu/LexUriServ/LexUriServ.do?uri=COM:2009:048 l:FIN:HU:PDF.
}

who.int/en/health-topics/communicable-diseases/influenza/pandemic-influenza/pandemic-influenza-preparedness-pip-framework).

Lényegében ezért kezdődött meg az uniós tagállamok között a WHO Európai Regionális Irodáján keresztül a keretrendszer kidolgozása, amelyet az Egészségügyi Világközgyúlés 2011-ben elfogadott. ${ }^{21}$ Ennek legfontosabb pillére az emberi pandémiás potenciállal rendelkező influenzavírusokkal összefüggő, a globális influenzafelügyeleti és reagálási rendszeren (GISRS) keresztül megvalósított hatékonyabb információmegosztás.

A keretrendszer elfogadásának 10. évfordulója alkalmával idén májusban a WHO megemlékezett az elért eredményekről, de megfogalmazta az alábbiakat is.

„Nagyon sok munka van még hátra. A COVID-19 számos hiányosságra és kibivásra hivta fel a figyelmet (pl.globális ellátási láncok kezelése vészhelyzet idején, klinikai túlfeszültség-kapacitás), és a levont tanulságok szintén megerösitik az influenzára való felkészültség és reagálás fontosságát... A világnak ébernek kell lennie a pandémiás potenciállal rendelkezô influenza vírusok iránt: bármelyik pillanatban megjelenhetnek.” (https://www.who.int/ news-room/feature-stories/detail/preventing-thenext-human-influenza-pandemic-celebrating-10-yearsof-the-pandemic-influenza-preparedness-framework)

Nem tartottuk feladatunknak azt, hogy a nemzetközi szabályozás valamennyi elemét és erófeszítését részletesebben bemutassuk. Annyit kívántunk jelezni ezzel az áttekintéssel, hogy meglehetősen komoly az a felelősségvállalás és elkötelezettség, amelyet mind a $\mathrm{WHO}$, mind pedig az EU képviselt az elmúlt másfél évtizedben, a pandémiás kihívásokra történő felkészülés színvonalának javítása területén. Ugyanakkor e globális szemléletmódot tükröző aktivitás sem 2009-ben, sem pedig 2019ben nem volt elegendő ahhoz, hogy globális cselekvőképességünk színvonalát új alapokra helyezze.

Az Egészségügyi Világközgyúlés 2021. május 31-én határozatot fogadott el arról, hogy novemberre tervezett rendkívüli ülésén megtárgyalja egy világjárványokról szóló új, kötelezố erejü nemzetközi szerzốdés előkészítését. Ezt megelőzően pedig megszerezte az EU elvi támogatását, amelyet a Tanács 2021. május 20-ai határozatában erősítettek meg. Pontosabban fogalmazva mindez azért nem előzmények nélkül történt.

Ugyanis éppen az Európai Tanács elnöke, Charles Michelnek vetette fel először 2020 novemberében a Párizsi Békefórumon egy ilyen nemzetközi szerződés ötletét, amelyet azt követően a G7-ek vezetói 2021. február 19-én megerősítettek. Az uniós vezetók ez után fogalmazták meg elkötelezettségüket a tekintetben, hogy az Egészségügyi Világszervezet keretében megkezdik a világjárványokról szóló nemzetközi szerződés előkészítésével kapcsolatos tevékenységet.

${ }^{21}$ https://www.who.int/initiatives/pandemic-influenza-preparedness-framework. 
2021. március 30-án pedig a Tanács sajtóközleményt adott ki, amelyben annak elnöke a WHO főigazgatójával közös, és a világ több mint 20 vezetője által támogatott felhívást tett közzé.

„A jövőben is lesznek újabb világjárványok és egyéb jelentôs egészségügyi szükséghelyzetek. A kérdés nem is az, hogy van-e ilyen veszély, hanem az, hogy mikor következik be. Együttesen kell felkészültebbnek lennünk arra, hogy fokozott koordinációval elóre jelezzük, megelozzzük, észleljük, felmérjük és evedményesen kezeljük a világjárványokat. Ezért úgy gondoljuk, hogy a nemzeteknek együtt kell munkálkodniuk egy, a világjárványokra való felkészültséget és az azokra való reagálást célzó új nemzetközi szerzódés kidolgozása érdekében... A Covid19 a gyengeségeinket és a megosztottságunkat használta ki, ezért most meg kell ragadnunk az alkalmat arra, hogy globális közösségként olyan békés együttmüködést alakitsunk ki, amely túlmutat a jelenlegi válságon. Az ebhez szükséges kapacitások és rendszerek kiépitése idót, valamint sok éven át fenntartott folyamatos politikai, pénzügyi és társadalmi elkötelezettséget igényel majd. ’22

Csak remélhetjük, hogy a világ ezt az utat választja.

\section{Összegzés}

Tanulmányunk három szempontból vizsgálta a világjárványt. Először áttekintettük azokat a jellemzőket, amelyek a COVID-19 egyediségét igazolják. Ilyennek tartjuk - a legnagyobb kockázat minőséget,

- a három veszélyforrás elméletet,

- a világjárvány és a természeti katasztrófák következményeinek nem összehasonlítható jellegét,

- a kockázatvállalás előzetes mérlegelésének kizárását,

- az elviselhető és az elviselhetetlen distinkció alkalmazását,

- a belső és külső kockázat tipológia követhetetlenségét,

- a jogalkotással nem prognosztizálható tulajdonságot,

- a következmények matematikai mérhetőségét, és

- a világgazdaságra gyakorolt hatást.

Második elhatározásunk az volt, hogy a járvány elleni küzdelem hazai gyakorlatát a különleges jogrenden keresztül mutatjuk be, támaszkodva a jogtudomány képviselőinek e tárgykörben 2020-tól megjelent értékeléseire. Áttekintettük a különleges jogrend alkotmányossági kérdéseit, a központi állam- és önkormányzati igazgatásra, a büntető anyagi és eljárási jogra, valamint a rendészeti igazgatásra gyakorolt hatásait.

A harmadik témakörben az Egészségügyi Világszervezetnek a járvány globális módon történő kezelésére figyeltünk. Az a meggyőződésünk, hogy ezt a hármas szempontot érdemes lesz követni akkor is, amikor már lehetőség nyílik a járványkezelés jó és rossz gyakorlatainak értékelésére. Ez azonban már a poszt-COVID korszak feladata lesz.

\footnotetext{
22 https://www.consilium.europa.eu/hu/press/press-releases/2021/03/30/ pandemic-treaty-op-ed/.
}

\section{Irodalomjegyzék}

Ambrus I. \& Hollán M. (2021) A fertőző betegségek elleni küzdelem a járvány idején büntetőjogban: régi problémák és új aspektusok a COVID-19 járvány idején. Magyar Tudomány, Vol. 182. No. 5. pp. 603-613.

Balázs I., Hoffman I. \& Hungler S. (2021) „Veled uram, de nélküled” - állam, önkormányzatok, munkáltatók a koronavírus idején. Magyar Tudomány, Vol. 182. No. 5. pp. 625-634.

Bencze M. \& Győry Cs. (2021) Hírek szárnyán: a rémhírterjesztés búncselekménye és a jogbiztonság. Magyar Tudomány, Vol. 182. No. 5. pp. 614-625.

Borbély Zs. (2021a) A járványügyi veszélyhelyzet megélése a próbaidős tiszthelyettesek körében. Magyar Rendészet, Vol. 21. No. 2. pp. $111-125$.

Borbély Zs. (2021b) Rendészeti tevékenység a koronavírus járvány idején. Belügyi Szemle, Vol. 69. No. 2. pp. 285-303.

Bukovics I. \& Kiss E. (2004) Beszélhetünk-e „kockázattársadalomról” Magyarországon. Belügyi Szemle, Vol. 52. No. 7-8. pp. 59-68.

Bukovics I., Kun I. \& Szendrő É. (2021) A járványkezelés számítógépes modellje. Ünnepi kötet a 80 éves Tamás András tiszteletére, Ludovika Egyetemi Kiadó

Éberhardt G. (202la) A koronavírus járvány rendészeti kezelése: A kollektív normasértés elemei és következményei. Belügyi Szemle, Vol. 69. No. 2.

Éberhardt G. (2021b) Magyarország az újabb tömeges migráció kapujában. Belügyi Szemle, Vol. 69. No. 3. pp. 345-374.

Farkas Á. (2020) Gondolatok a koronavírus-járvány és a védelmi, biztonsági szabályozás kölcsönhatásairól, Belügyi Szemle, Vol. 68. No. 5 .

Fábián A. (2021) Közigazgatás - (egészségügyi) veszélyhelyzetben. Ünnepi kötet a 80 éves Tamás András tiszteletére, Ludovika Egyetemi Kiadó

Finszter G. (2019) A vállalható és a nem vállalható kockázatok. In: Finszter G. - Korinek L. (szerk.): A rend kedvéért. Magánkiadás

Gárdos-Orosz F. \& Pap A. L. (2021) A járvány kezelésének alkotmányjogi vonatkozásai. Magyar Tudomány, Vol. 182. No. 5., 583592

Heller Á. (2001) A történelem elmélete. Budapest: Múlt és Jövő Lapés Könyvkiadó

Herke Cs. \& Sándor B. (2020) A nyomozás egyes problémái az új koronavírus miatti veszélyhelyzet idején. Rendőrségi Tanulmányok, No. 2

Hoffmann T., Marton P. \& Lukasz Gruszczynski, L. (2021) Az állam felelőssége a SARS-COV-2 járvány feltartóztatásához, mint nemzetközi betegségmegelőzéshez kapcsolódóan. Magyar Tudomány, Vol. 182. No. 5. 593-602.

Horváth B. (2001) Angol jogelmélet. Budapest: Pallas Stúdió Attraktor $\mathrm{Kft}$.

Huntington, S. P. (1994) A katona és az állam. Budapest: Zrínyi Kiadó-Atlanti Kutató és Kiadó

Irk F. (2004) Biztonságérzet a rizikótársadalomban? Emlékkönyv Irk Albert egyetemi tanár születésének 120. évfordulójára, Pécs

Irk F. (2015) Megbüntethetetlen bünök I. Transznacionális gazdálkodó szervezetek kockázatmenedzselése. Miskolc: Bíbor Kiadó

Irk F. (2021) Kétkedő kriminológia. A rizikótársadalom kriminálszociológiája. Miskolc: Bíbor Kiadó

Jennings, W. G. \& Perez, N. M. (2020): The Immediate Impact of COVID-19 on Law Enforcement in the United States. Vol. 45. No. 4. pp. 690-701.

Lakatos L. (2014) A különleges jogrend és a honvédelem szabályozása. Budapest: Magyar Tudományos Akadémia

Nagy I. (2020) A COVID-19 közvetlen hatása a rendészetre az Egyesült Államokban. In: Jennings, Wesley G., Perez, Nicholas M. (2020): The Immediate Impact of COVID-19 on Law Enforcement in the United States. Vol. 45. No. 4. 690-701. (Recenzió kézirata)

Póczik Sz., Sárik E., Vass P. \& Bolyky O. (2021) A COVID-19 pandémia egyes kriminológiai aspektusai. Belügyi Szemle, Vol. 69. No. 3. 
Ritter I. (2020) Karanténban a drogpiac? A COVID-19 pandémia hatásai a globális drogpiacra. Ügyészség Lapja, Ügyészek Országos Egyesülete, No. 4-5.

Skorka T. (2021) Koronavírus a szabálysértés szemszögéből, Magyar Rendészet, No. 1.

Szúcs A. (2020) „A kormányozhatatlan kormányzása” - Ki irányítja a világpolitikát? Magyar Tudomány, Vol. 181, No. 8. pp. 1107-1124.

Vizvári F. (2021) Közalkalmazottak a COVID-19 járvány alatt: Rendőri válaszok kényszerhelyzetben. Belügyi Szemle Vol. 69. No. 2.

\section{Jogforrások}

Magyarország Alaptörvénye

1948. évi XII. törvény az Egészségügyi Világszervezet Alkotmányának becikkelyezéséről

1994. évi XXXIV. törvény a rendőrségről

1997. évi CLIV. törvény az Egészségügyről

2009. évi XCI. törvény az Egészségügyi Világszervezet Nemzetközi Egészségügyi Rendszabályainak kihirdetéséről

2011. évi CXIII. törvényt a honvédelemről és a Magyar Honvédségről, valamint a különleges jogrendben bevezethető intézkedésekról

2011. évi CXXVIII. törvény a katasztrófavédelemről és a hozzá kapcsolódó egyes törvények módosításáról

2012. évi II. törvény a szabálysértésekről és a szabálysértési nyilvántartásról

2020. évi XII. törvény a koronavírus elleni védekezésről

2020. évi LIX. törvény a különleges gazdasági övezetrôl és a hozzá kapcsolódó egyes törvények módosításáról

2020. évi LVIII. törvény a veszélyhelyzet megszúnésével összefüggô átmeneti szabályokról és a járványügyi készültségről

40/2020. (III. 11.) Korm. rendelet a veszélyhelyzet kihirdetéséról

41/2020. (III. 11.) Korm. rendelet az élet- és vagyonbiztonságot veszélyeztető tömeges megbetegedést okozó humánjárvány megelőzése, illetve következményeinek elhárítása, a magyar állampolgárok egészségének és életének megóvása érdekében elrendelt veszélyhelyzet során teendő intézkedésekről

81/2020. (IV. 1.) Korm. rendelet az egészség és élet megóvása, valamint a nemzetgazdaság helyreállítása érdekében elrendelt veszélyhelyzettel kapcsolatos rendkívüli intézkedésekről

135/2020. (IV. 17.) Korm. rendelet a veszélyhelyzettel összefüggésben a nemzetgazdaság stabilitásának érdekében szükséges intézkedésekről

72/2020. (III. 28.) Korm. rendelet a kórházparancsnokról és az egészségügyi készlet védelméról

74/2020. (III. 31.) Korm. rendelet a veszélyhelyzet ideje alatt érvényesülő egyes eljárásjogi intézkedésekről

95/2020. (IV. 9.) Korm. rendelet a kijárási korlátozások meghosszabbításáról

$367 / 2021$. (VI. 30.) Korm. rendelet a kórházparancsnoki és intézményparancsnoki feladatok ideiglenes szüneteltetéséről

181/2020. (V. 4.) Korm. rendelet az élet- és vagyonbiztonságot veszélyeztető tömeges megbetegedést okozó humánjárvány vonatkozásában elrendelt hatósági házi karantén elektronikus ellenőrzéséről

1012/2020. (I. 31.) Korm. határozat a Koronavírus-járvány Elleni Védekezésért Felelős Operatív Törzs felállításáról
287/2020. (VI. 17.) Korm. rendelet az egészségügyi készlet állagának megóvása érdekében szükséges intézkedésekről

71/2020. (III. 27.) Korm. rendelet a kijárási korlátozásokról

WHO 58.3 számú határozat

\section{Internetes források}

https://www.consilium.europa.eu/hu/press/press-releases/2021/ $03 / 30 /$ pandemic-treaty-op-ed/

https://eur-lex.europa.eu/legal-content/hu/TXT/?uri= CELEX\%3A52005DC0607

https://eur-lex.europa.eu/legalcontent/HU/TXT/PDF/?uri=CEL EX:32004R0851\&qid $=1626249351348 \&$ from $=H U$

https://eur-lex.europa.eu/LexUriServ/LexUriServ.do?uri= COM:2009:0481:FIN:HU:PDF

https://www.euro.who.int/en/health-topics/communicable-diseases/influenza/pandemic-influenza/pandemic-influenza-preparedness-pip-framework

https://www.who.int/initiatives/pandemic-influenza-preparednessframework

https://www.who.int/news-room/feature-stories/detail/preventing-the-next-human-influenza-pandemic-celebrating-10-years-ofthe-pandemic-influenza-preparedness-framework

https://www.consilium.europa.eu/hu/press/press-releases/2021/ $03 / 30 /$ pandemic-treaty-op-ed/

https://www.who.int/docs/default-source/coronaviruse/situationreports $/ 20200130$-sitrep-10-ncov.pdf?sfvrsn=d0b2e480_2

https://www.who.int/emergencies/diseases/novel-coronavirus-2019/interactive-timeline\#!

https://www.who.int/docs/default-source/coronaviruse/situationreports $/ 20200229$-sitrep-40-covid-19.pdf?sfvrsn=849d0665_2

https://www.who.int/director-general/speeches/detail/who-director-general-s-opening-remarks-at-the-mission-briefing-on-covid19---13-march-2020

https://hvg.hu/itthon/20210710

https://www.who.int/publications/m/item/weekly-epidemiological-update-on-covid-19---6-july-2021

https://mta.hu/tudomanyunnep2020/karsai-marton-fertozesterjedesek-adatalapu-modellezese-avagy-halozatok-a-koronavirus-jarvany-modellezesenek-szolgalataban-111049

https://mok.hu/koronavirus/tajekoztatok/post-covid-szindromadiagnosztika-es-protokoll

https://www.who.int/director-general/speeches/detail/who-director-general-s-remarks-at-the-member-state-briefing-on-the-reportof-the-international-team-studying-the-origins-of-sars-cov-2

https://www.who.int/news-room/feature-stories/detail/preventing-the-next-human-influenza-pandemic-celebrating-10-years-ofthe-pandemic-influenza-preparedness-framework

https://www.cdc.gov/flu/pandemic-resources/2009-hlnl-pandemic.html

https://mta.hu/mta_hirei/a-post-covid-jelensegek-vizsgalatarahirdet-palyazatot-az-mta-111493

https://mta.hu/data/dokumentumok/egyeb_dokumentumok/ 2021/MTU-brosura-2020-PRESS-4_Vegleges_dec_03.pdf

A cikk a Creative Commons Attribution 4.0 International License (https://creativecommons.org/licenses/by-nc/4.0/) feltételei szerint publikált Open Access közlemény, melynek szellemében a cikk bármilyen médiumban szabadon felhasználható, megosztható és újraközölhető, feltéve, hogy az eredeti szerző és a közlés helye, illetve a CC License linkje és az esetlegesen végrehajtott módositások feltüntetésre kerülnek. 